\title{
Diagnosis of the Physical Area of Community-Dwelling Adults
}

\author{
Judith Margarita Rodríguez-Villalobos, Martha Ornelas Contreras, \\ José René Blanco Ornelas, Gabriel Gastélum Cuadras, Cynthia Vannesa Gibbs Celis* \\ Faculty of Physical Culture Sciences, Autonomous University of Chihuahua, Chihuahua, México \\ Email: ${ }^{*}$ cgibbs@uach.mx
}

Received 12 September 2014; revised 19 October 2014; accepted 19 November 2014

Copyright (C) 2014 by authors and Scientific Research Publishing Inc.

This work is licensed under the Creative Commons Attribution International License (CC BY). http://creativecommons.org/licenses/by/4.0/

c) (i) Open Access

\begin{abstract}
A situational analysis of aspects related to the physical area of elderly residents of permanent stay of the city of Chihuahua was performed. Participating in the study 51 subjects, 30 women and 21 men, Tinetti and trunk flexion EUROFIT scales were applied to assess fall risk and range of motion. The poor results in balance, gait and range of motion can be stated that most of them are in serious risk of falling. The results obtained show the urgency of starting a physical activation program that emphasizes directly in recovery mobile independence so that enable seniors asylees enhance your ability to perform activities of daily life and reduce the burden on their caregivers.
\end{abstract}

\section{Keywords}

Situation Assessment, Elderly, Physical Area, Fall Risk

\section{Introduction}

As people age, changes occur in your health: altered structures and functions of cells are reduced, and the tissues of all body systems. Older people are thus in a difficult situation, since the loss of body control involves the loss of other skills of interaction and real social power due to the decline of these powers, that is, with advancing age the physical abilities deteriorate and health problems [1]-[3]. Today nine out of 100 Mexicans are 60 years or older and agree with the growth rate presented between 2000 and 2010, this population is expected to double in 18.4 years [4], for what Mexico has only a few decades to prepare the institutional responses that allow addressing these demographic trends.

More specifically for the state of Chihuahua, Mexico data, the National Institute of Statistics, Geography and Informatics [5] indicates that $12.5 \%$ of the general populations are elderly and it is estimated that by 2025 that

"Corresponding author.

How to cite this paper: Rodríguez-Villalobos, J.M., Contreras, M.O., Ornelas, J.R.B., Cuadras, G.G. and Celis, C.V.G. (2014) Diagnosis of the Physical Area of Community-Dwelling Adults. Advances in Aging Research, 3, 388-393.

http://dx.doi.org/10.4236/aar.2014.35049 
figure increased approximately one quarter of the total population. This information begs the expectation of the needs for health services, social services and human development that will demand attention to this sector of the population that is increasing. Currently in the state of Chihuahua there has the option for the care of older stays in permanent residence, institutions receiving the elderly for care.

Most of these institutions do not have consistent comprehensive geriatric assessment in the diagnosis and detection of multidimensional deficits in clinical-medical , functional, mental, physical and social areas, in order to achieve a rational and integrated plan for treatment and follow-up [6] [7].

Due to the above, it is clear that the need for Community-Dwelling for older adults, has a systematic geriatric assessment of hospitalized adults to identify and quantify the physical, functional, psychological and social problems that can present the elderly, in order to develop a treatment plan and follow-up of these problems as well as the optimal use of resources.

This study's main objective is to answer the question: what is the current situation of the elderly residents of Community-Dwelling of the city of Chihuahua in their physical realm? Providing evidence and data which enable efficiency in the permanent residence is in order to improve the quality of life elderly adults.

\section{Method}

\subsection{Participants}

Participants in the study included 51 older adults, 30 women and 21 men, residents of 4 Community-Dwelling houses of the city of Chihuahua who had a medical condition that allowed them to be valued and accepted to participate in the study. The age of the subjects ranged between 60 and 98 years, with a mean of 81 and a standard deviation of 8.5 years. The study was approved by the research committee of the Faculty of Physical Culture Sciences of the Autonomous University of Chihuahua.

\subsection{Instruments}

Tinetti Scale, subscales assessing balance and gait: The two subscales are implementing or direct observation and assess the ability of an individual to perform a certain physical activity. Subscale I: Balance (9 items), assesses the different components of balance: sitting, getting up, sitting, in standing, etc. Subscale II: March (7 items), assesses the speed of walking, stride length, base of support, the regularity of the steps and the temporal relationship between the phases of support and bipodal-unipodal support. A score of 26 to 28 is considered normal, 19 - 25 with some risk of falling, and a lower score of 19, 5 times more risk.

Trunk flexion. Distance traveled by the tip of the middle finger in the thigh during the (right, left) lateral flexion as a result of the application of lateral trunk flexion test European fitness test for adults (EUROFIT).

\subsection{Procedure}

Once established collaboration agreements with participating homes and signed consents by older adults with a medical condition that would allow him to participate in the study. We proceeded with the implementation of the instruments battery that make the proposal for situation assessment of physical area, in approximately two consecutive work sessions, by elderly, for about an half an hour each session. Finally we proceeded to the analysis of the data obtained.

\subsection{Data Analysis}

Frequency analysis and correlation were carried out among the studied categories (normal, with some risk of falling and 5 times the risk of falling). Subsequently, after verifying that the data met the assumptions of parametric statistical analyses, a one-way multivariate analysis of variance (MANOVA), followed by the one-way univariate analysis of variance (ANOVA), were used to examine the differences on trunk flexion, balance and gait variables; taking gender and age as an independent variables. All statistical analyses were performed using the SPSS version 20.0 for Windows (IBM ${ }^{\circledR}$ SPSS $^{\circledR}$ Statistics 20). The statistical significance level was set at $\mathrm{p}<$ 0.05 .

\section{Results}

Frequency Analysis by gender and age, the application of the Tinetti scale: In terms of gender, the pattern of risk 
of falls is very similar (Figure 1). While age the risk of falls increases dramatically, $\mathrm{X}^{2}(2, \mathrm{~N}=51)=6.999, \mathrm{p}<$ 0.05 (Figure 2). In addition most of the elderly (80\%) have a high risk of falling (Figure 2).

The multiple analysis of variance taking gender as an independent variable (first) and age (second) and as dependents trunk flexion left and right variables showed significant differences only on the left with respect to age, $\mathrm{F}(1,49)=5.617, \mathrm{p}<0.05$ (Figure 3 and Figure 4).

The multiple analysis of variance taking gender as an independent variable (first) and age (second) and as dependent as balance and gait variables Tinetti scale, in terms of gender, there were no differences. With respect to age, differences in gait, $\mathrm{F}(1,49)=6.825, \mathrm{p}<0.05$, and balance, $\mathrm{F}(1,49)=4.487, \mathrm{p}<0.05$, were significant (Figure 5 and Figure 6).

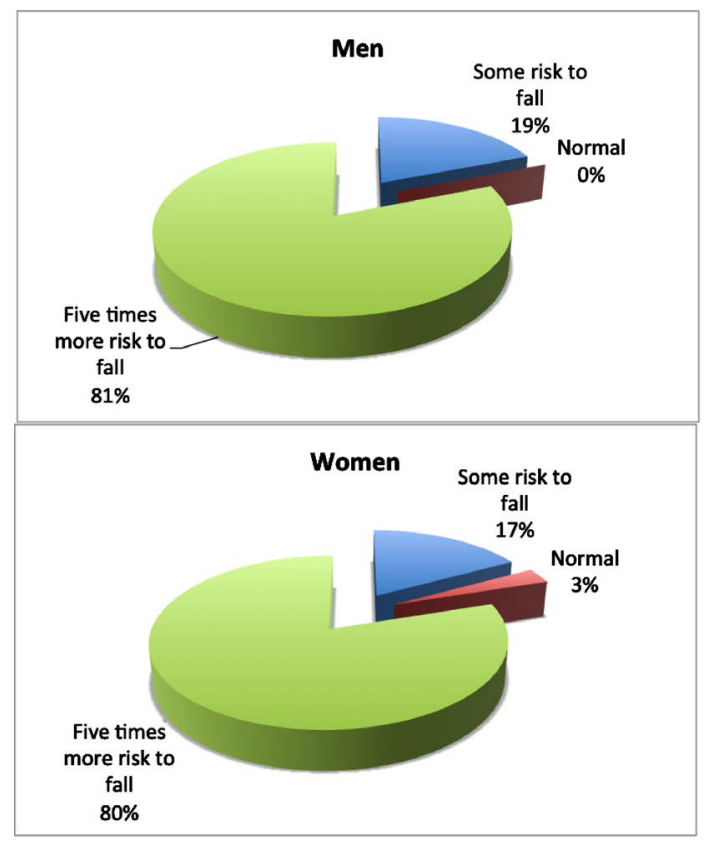

Figure 1. Tinetti scale according to gender.

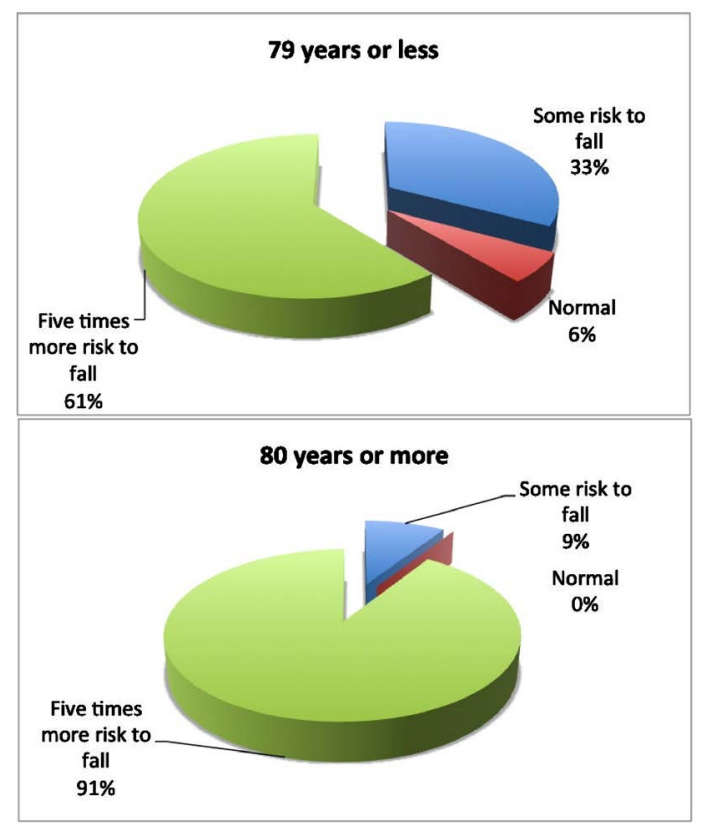

Figure 2. Tinetti scale according to age. 


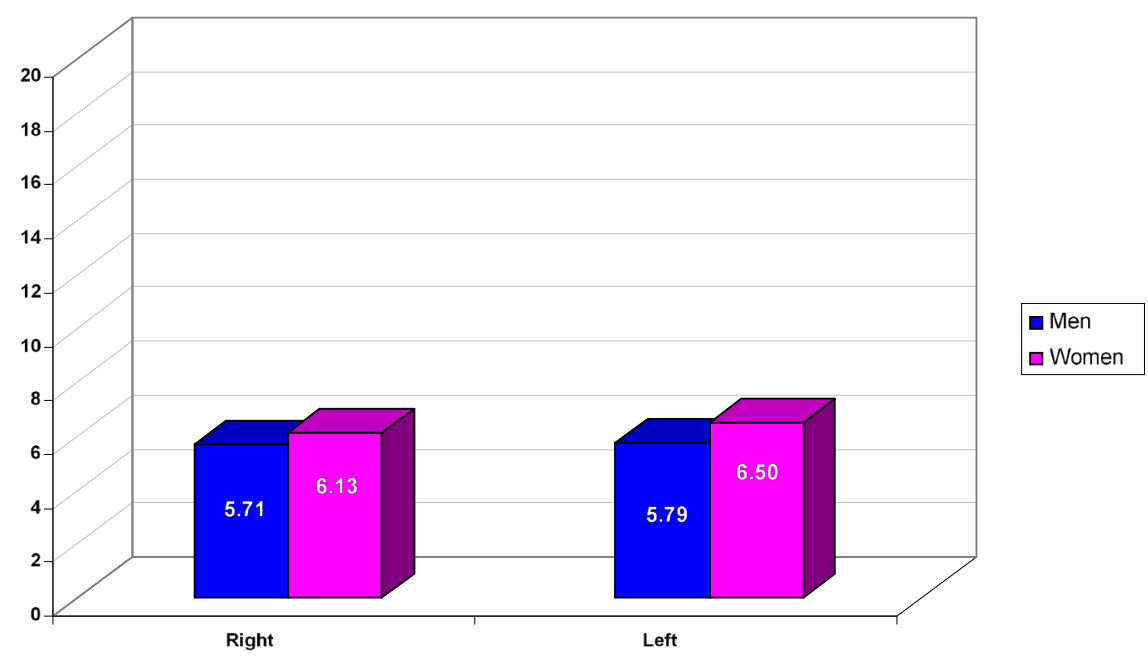

Figure 3. Average trunk flexes according to gender.

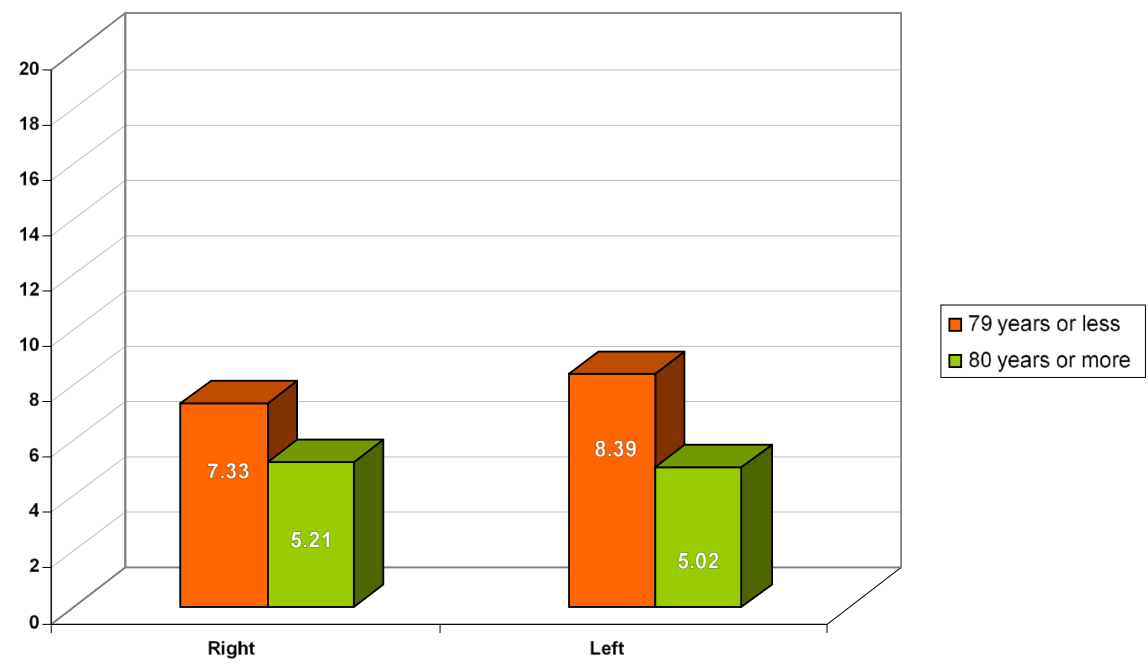

Figure 4. Average trunk flexes according to age.

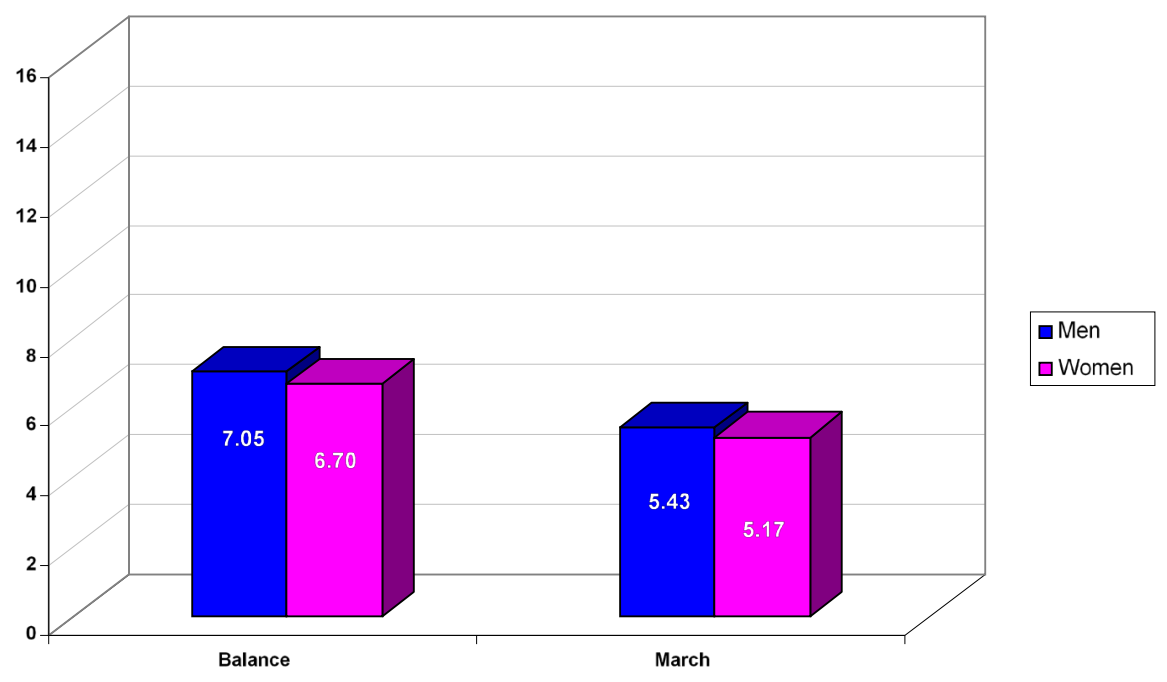

Figure 5. Average ratings in balance and walking according to gender. 


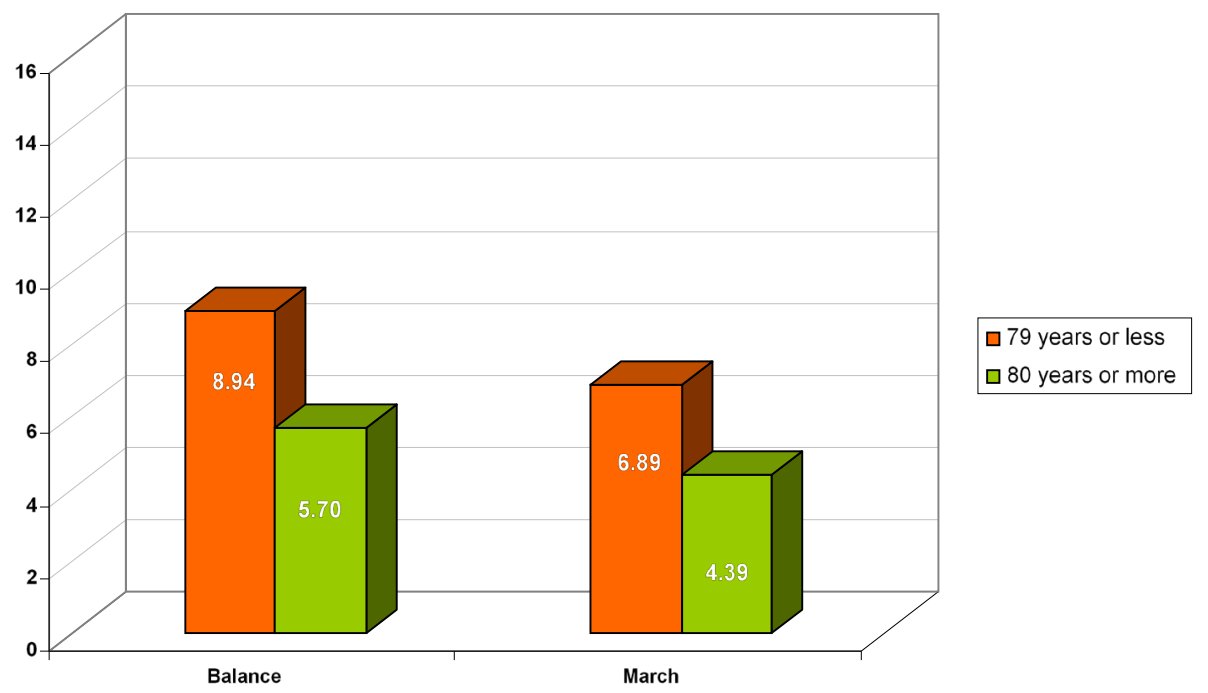

Figure 6. Average ratings in balance and walking according to age.

\section{Discussions}

According to results in poor balance and gait in older adults, according to the Tinetti scale, we can say that most of them are in serious risk of falling, which coincides with the findings of Vera and Campillo [8]. As for trunk flexion of older adults, the results show a significant deterioration with age limiting their independence and ability to perform activities of daily life; which directly or indirectly affects their quality of life.

We must mention that the main limitation of the present study is the reduced sample size that includes only people who are living in nursing homes and do not apply to those elderly who live outside of these residences.

\section{Conclusion}

It is necessary to recognize that there are limitations in the diagnosis made in quantity and quality of assessment indexes used, the results obtained and the conclusions that follow from this point to the need for a systematic assessment in the halls of permanent residence, and the urgency of starting a physical activation program that emphasizes in the recovery of motor independence so as to allow the elderly inmates to improve their ability to perform activities of daily living and reduce the burden of their caregivers.

\section{Acknowledgements}

This study is part of a project funded by the Secretaría de Educación Pública—Subsecretaría de Educación Superior-Dirección General de Educación Superior Universitaria de México [Mexican Ministry of Education-Department of Higher Education-General Directorate of the University Education] (OF-13-6894). Additionally, the first and third authors are supported by a grant from the National Council of Science and Technology of Mexico (Conacyt).

\section{References}

[1] Aguilar, S.G., Fuentes, A., Ávila, J.A. and García, E.J. (2007) Validity and Reliability of Questionnaire ENASEM for Depression in Older Adults. Public Health of Mexico, 49, 256-262.

[Aguilar, S.G., Fuentes A., Ávila J.A. and García E.J. (2007) Validez y confiabilidad del cuestionario del ENASEM para la depresión en adultos mayores. Salud Pública de México, 49, 256-262.] http://dx.doi.org/10.1590/S0036-36342007000400005

[2] Herranz, I., Lirio, J., Portal, E. and Arias, E. (2013) Physical Activity as an Element of Participation and Quality of Life in Older People. Psychological Writings, 6, 13-19.

[Herranz, I., Lirio, J., Portal, E. and Arias, E. (2013) La actividad física como elemento de participación y calidad de vida en las personas mayores. Escritos de Psicología, 6, 13-19.] http://dx.doi.org/10.5231/psy.writ.2013.1906

[3] Manrique-Espinoza, B., Salinas-Rodríguez, A., Moreno-Tamayo, K. and Téllez-Rojo, M.M. (2011) Prevalence of 
Functional Dependency and Its Association with Falls in a Sample of Elderly Poor in Mexico. Public Health of Mexico, 53, 26-33.

[Manrique-Espinoza, B., Salinas-Rodríguez, A., Moreno-Tamayo, K. and Téllez-Rojo, M.M. (2011) Prevalencia de dependencia funcional y su asociación con caídas en una muestra de adultos mayores pobres en México. Salud Pública de México, 53, 26-33.]

[4] National Institute of Statistics, Geography and Informatics (2010) Census of Population and Housing 2010. National Institute of Statistics, Geography and Informatics, Mexico.

[Instituto Nacional de Estadística Geografía e Informática (2010) Censo de Población y Vivienda 2010. Instituto Nacional de Estadística, Geografía e Informática, México.]

[5] National Institute of Statistics, Geography and Informatics (2005) Older Adults in Mexico. Sociodemographic Profile at the Beginning of XXI Century. National Institute of Statistics, Geography and Informatics, Mexico.

[Instituto Nacional de Estadística Geografía e Informática (2005) Los adultos mayores en México. Perfil sociodemográfico al inicio del siglo XXI. Instituto Nacional de Estadística, Geografía e Informática, México.]

[6] Cervera, M.D.C. and Saiz, J. (2006) Update in Geriatrics and Gerontology I. Formacion Alcalá S. L., España. [Cervera, M.D.C. and Saiz, J. (2006) Actualización en geriatría y gerontología I. Formacion Alcalá S. L., España.]

[7] Durante, P. and Pedro, P. (2010) Geriatric Occupational Therapy: Principles and Practice. MASSON, Barcelona. [Durante, P. and Pedro, P. (2010) Terapia ocupacional en geriatría: principios y práctica. MASSON, Barcelona.]

[8] Vera, M. and Campillo, R. (2003) Assessment of Gait and Balance as a Risk Factor in Falls among the Elderly. Cuban Journal of General Medicine, 19.

[Vera, M. and Campillo, R. (2003) Evaluación de la marcha y el equilibrio como factor de riesgo en las caídas del anciano. Revista Cubana de Medicina General Integral, 19.] 
Scientific Research Publishing (SCIRP) is one of the largest Open Access journal publishers. It is currently publishing more than 200 open access, online, peer-reviewed journals covering a wide range of academic disciplines. SCIRP serves the worldwide academic communities and contributes to the progress and application of science with its publication.

Other selected journals from SCIRP are listed as below. Submit your manuscript to us via either submit@scirp.org or Online Submission Portal.
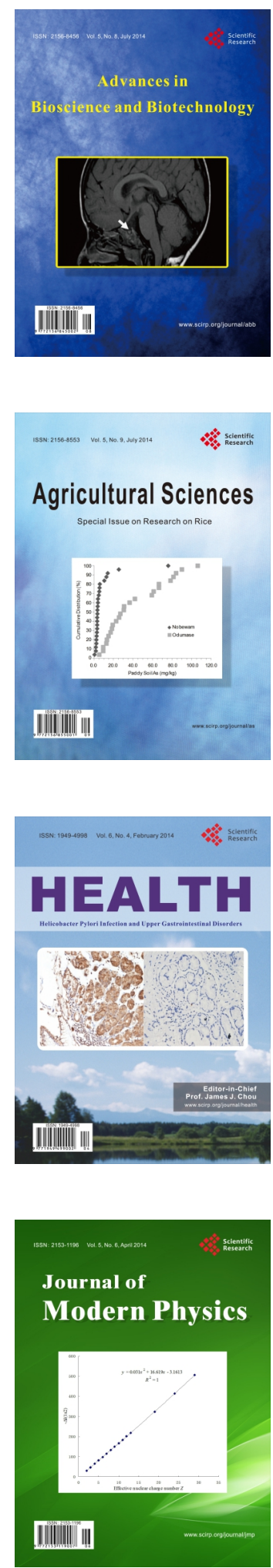
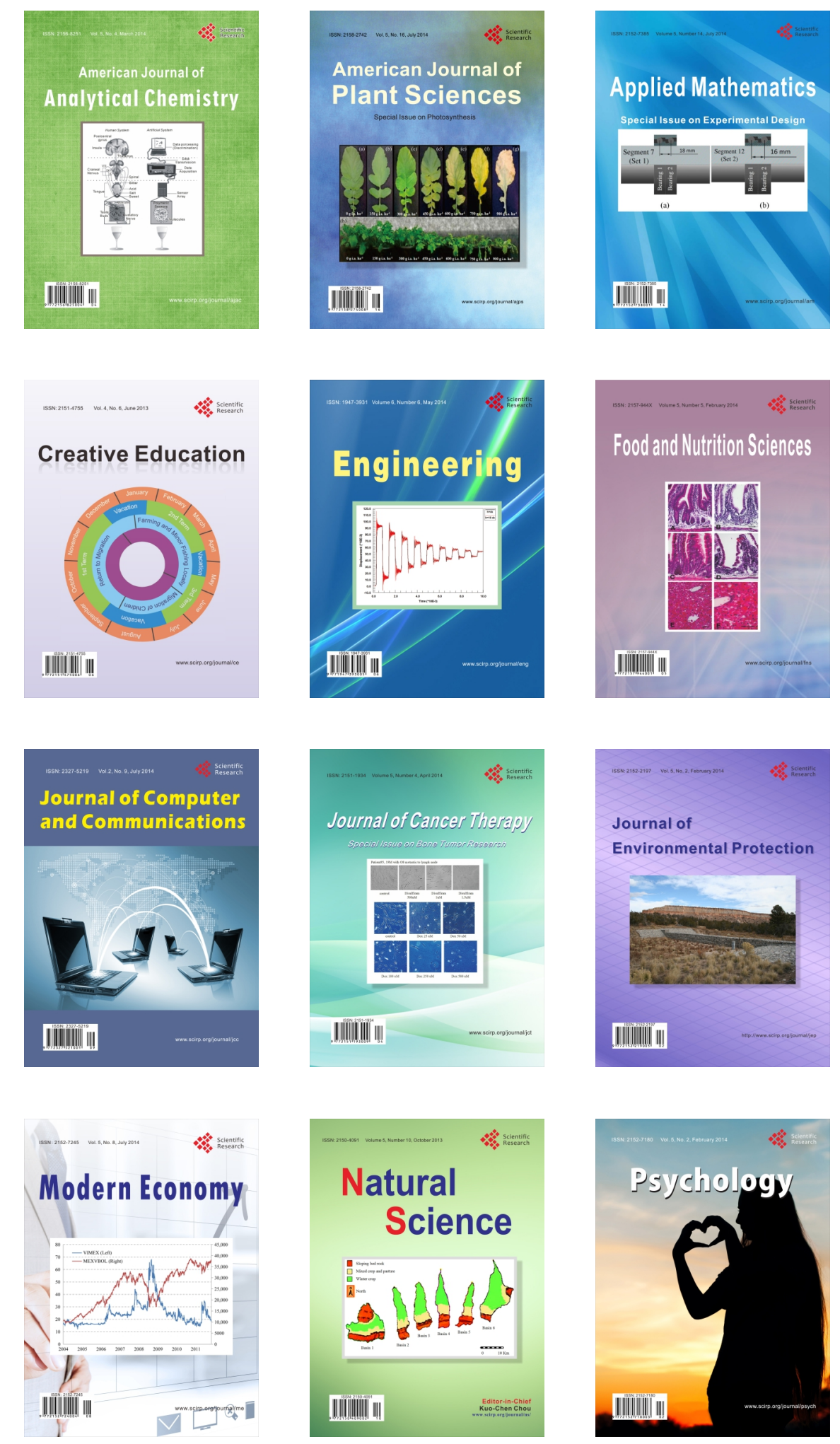